\title{
Dopamine Deficiency in a Genetic Mouse Model of Lesch-Nyhan Disease
}

\author{
H. A. Jinnah, ${ }^{1}$ B. E. Wojcik, ${ }^{1}$ M. Hunt, ${ }^{2}$ N. Narang, ${ }^{2}$ K. Y. Lee, ${ }^{3}$ M. Goldstein, ${ }^{3}$ J. K. Wamsley, ${ }^{2}$ P. J. Langlais, ${ }^{4}$ \\ and T. Friedmann ${ }^{1}$ \\ 'Departments of Neurosciences and Pediatrics, Center for Molecular Genetics, University of California San Diego School \\ of Medicine, La Jolla, California 92093, ${ }^{2}$ Neuropsychiatric Research Institute, Fargo, North Dakota 58107, ${ }^{3}$ Neurochemistry \\ Research Laboratories, New York University Medical Center, New York, New York 10016, and ${ }^{4}$ San Diego Veterans \\ Administration Medical Center and San Diego State University Department of Psychology, San Diego, California 92161
}

We have examined several aspects of neurotransmitter function in the brains of mice carrying a deletion mutation in the gene encoding the purine salvage enzyme hypoxanthine-guanine phosphoribosyltransferase (HPRT). During the first 6 weeks of postnatal development, dopamine levels in whole-brain extracts from the mutant mice (HPRT-) failed to increase at rates comparable to normal animals, resulting in $\mathbf{4 0} \%$ lower dopamine levels throughout adulthood. Regional analysis in adult animals showed the caudoputamen to be the most severely affected region, with dopamine deficits of 48-64\%. Dopamine levels in other regions were normal or less severely affected. The decrease in dopamine was accompanied by a decrease in tyrosine hydroxylase (TH) activity, the rate-limiting step in dopamine synthesis. Kinetic analysis of TH extracted from the caudoputamen of normal and HPRT- mice demonstrated a $45 \%$ decrease in $V_{\max }$ with an increased affinity for the tetrahydropterin cofactor in the mutants. Labeling of midbrain dopamine neurons using TH immunohistochemistry revealed no obvious deficits in the number of midbrain dopamine neurons, but quantitative autoradiographic studies revealed significant reductions in the binding of ${ }^{3} \mathrm{H}-\mathrm{N}-[1$-(2-benzo $(\beta)$ thiophenyl)cyclohexyljpiperidine ( ${ }^{3} \mathrm{H}-\mathrm{BTCP}$ ) to dopamine uptake sites in the forebrain of the mutants. In contrast to these abnormalities of the dopamine systems in the mutant mice, other neurotransmitter systems appeared relatively unaffected. Norepinephrine, 5-HT, tryptophan hydroxylase, and glutamic acid decarboxylase were present at normal levels in the brains of the mutants. ChAT activity was slightly lower than normal in the caudoputamen of the mutant animals, but was normal in all other brain regions examined. These results indicate that HPRT deficiency is associated with a relatively specific def-

\footnotetext{
Received May 26, 1996; accepted Aug. 9, 1993.

We thank Dr. David Whittingham (MRC Experimental Embryology and Teratology Ynit, St. George's Hospital Medical School, I ondon) for generously providing mice carrying the HPRT deletion mutation. We also thank Drs. E. J. Hess and F. L. Levine for reading the manuscript, and P. Clopton for his advice on statistical analyses. This work was supported by the Medical School Training Program grant at UCSD (H.A.J.); NIH Grants HD20034 (T.F.), RR04754 (P.J.L.), and VA Merit Program Award (P.J.L.)

Correspondence should be addressed to Theodore Friedmann, M.D., at the above address.

Copyright (C) 1994 Society for Neuroscience $0270-6474 / 94 / 141164-12 \$ 05.00 / 0$
}

icit in basal ganglia dopamine systems that emerges during the first 2 months of postnatal development.

IKey Words: hypoxanthine-guanine phosphoribosyltransferase, animal model, neurogenetics, neurochemistry!

Our understanding of the pathophysiologic processes underlying a number of neurologic disorders has been greatly facilitated by the development of appropriate animal models. A number of hereditary mouse models discovered as spontaneous occurrences have been identified. These include models for seizure disorders (Fisher, 1989), lysosomal storage diseases (Kobayashi et al., 1980; Birkenmeier et al., 1988), disorders of myelination (Nave et al., 1986; Popko et al., 1987; Readhead ct al., 1987) neuromuscular disease (Sicinski et al., 1990), and neurodegenerative or developmental processes (Epstein et al., 1991; Messer et al., 1992). In addition to the spontaneous mutants, the availability of techniques to generate mice carrying specific genes or mutations in specific genes provides the opportunity to generate hereditary mouse models of specific human genetic diseases (Jaenisch, 1988; Rossant, 1990). For example, mutant strains of mice carrying defects in the genes encoding the purine salvage enzyme hypoxanthine-guanine phosphoribosyltransferase (HPRT) and the lysosomal enzyme glucocerebrosidase have been produced as homologous genetic animal models for Lesch-Nyhan disease and Gaucher disease, respectively (Hooper et al., 1987; Kuehn et al., 1987; Tybulewicz et al., 1992). As a greater number of mutations responsible for human diseases are identified, it seems likely that additional mouse mutants will be developed.

Mice carrying mutations in specific genes often exhibit a phenotype that bears an obvious resemblence to humans carrying homologous mutations, but, in other cases the mice display a phenotype that is quite different from that observed in the human (Erickson, 1989; Darling and Abbott, 1992). In fact, several genetically homologous mouse models exist for which an abnormal phenotype is not overtly apparent. For example, mutations in the dystrophin gene have been identified as the cause of the neuromuscular disease in both $m d x$ mice and patients with Duchenne's muscular dystrophy (Hoffman et al., 1987; Sicinski et al., 1990). However, in contrast to the progressively disabling muscular weakness observed in patients with Duchenne's disease, $m d x$ mice appear to suffer no overt impairment. Despite the absence of overt neurobehavioral abnormalities, these animals have proven useful for studying the 
histopathologic and biochemical consequences of the disease (Fong et al., 1990; Menke and Jockusch, 1991; Mehler et al., 1992; Dunn et al., 1993).

The HPRT ${ }^{-}$mouse model also presents a phenotype different from that of human patients with Lesch-Nyhan disease. Although Lesch-Nyhan patients display a number of neurobehavioral impairments including choreoathetosis, dystonia, mental retardation, and compulsive aggressive and self-injurious behavior (Emmerson and Thompson, 1973; Nyhan, 1973; Christie et al., 1982; Watts et al., 1982; Kelley and Wyngaarden, 1983), the HPRT- mice display no obvious neurobehavioral abnormalities (Finger et al., 1988; Jinnah et al., 1991, 1992b). Despite the absence of neurobehavioral deficits in these mice, several studies have demonstrated neurochemical abnormalities that are strikingly similar to those observed in Lesch-Nyhan disease. In particular, these animals have significant deficits in brain dopamine levels (Finger et al., 1988; Dunnett and Sirinathsinghji, 1989; Williamson et al., 1991; Jinnah et al., 1993) similar to those that occur in Lesch-Nyhan patients (Lloyd et al., 1981; Silverstein et al., 1985; Jankovic et al., 1988). The occurrence of this defect in the HPRT- mice provides a unique tool for studying the relationship between HPRT deficiency and brain dopamine systems. In the present studies, we have examined the basis of the abnormalities of the dopamine systems in the brains of the HPRT ${ }^{-}$mice.

\section{Materials and Methods}

Materials. Chemicals were obtained from Sigma Chemical Co. (St. Louis, MO), except for 3-hydroxybenzylhydrazine (NSD 1015) and GBR 12909, which were obtained from Research Biochemical International (Natick, MA). The ${ }^{14} \mathrm{C}$-tyrosine, ${ }^{14} \mathrm{C}$-acetyl coenzyme $\mathrm{A}$, and ${ }^{14} \mathrm{C}-\mathrm{L}$ glutamic acid (specific activities, $45-55 \mathrm{mCi} / \mathrm{mmol}$ ) were obtained from Amersham (Arlington Heights, IL). The ${ }^{3} \mathrm{H}-\mathrm{N}-[1-(2-$ ben$\mathrm{zo}(\beta)$ thiophenyl)cyclohexyl] piperidine ( ${ }^{3} \mathrm{H}$-BTCP; specific activity, 52 $\mathrm{Ci} / \mathrm{mmol}$ ) was obtained from DuPont-New England Nuclear (Boston, MA). Conical polypropylene tubes, rubber stoppers, and centerwells for $\mathrm{CO}_{2}$ trapping assays were obtained from Fisher/Kontes (Vineland, NJ).

Animals. Mice carrying a deletion mutation in the HPRT gene (Hooper et al., 1987) were maintained in a colony for 6-12 generations by congenic breeding with $\mathrm{C} 57 \mathrm{BL} / 6 \mathrm{~J}$ mice (Jackson Laboratories, Bar Harbor, ME). Previous studies have shown that mice carrying this mutation have a complete absence of HPRT enzyme activity in brain tissue (Jinnah et al., 1993). Animals were maintained on a $12 \mathrm{hr}: 12 \mathrm{hr}$ light/dark cycle with free access to food and water. All HPRT-normal (HPRT ${ }^{+}$) and HPRT-deficient $\left(\mathrm{HPRT}^{-}\right)$animals were identified by measuring HPRT activity in a $20 \mu \mathrm{l}$ sample of blood obtained from the tail (Jinnah et al., 1993).

Measurement of monoamines and their metabolites. Mice were killed by cervical dislocation. Their brains were removed, rinsed briefly in ice-cold saline, and dissected on an ice-cooled platform. Whole brains or subregions including the olfactory bulbs, caudoputamen, accumbens (with olfactory tubercle), cortex, hippocampus, diencephalon, mesencephalon, brainstem, and cerebellum were collected into tubes and frozen at $-70^{\circ} \mathrm{C}$ until analysis. Frozen samples were homogenized in at least $5 \mathrm{vol}$ of ice-cold $50 \mathrm{~mm}$ sodium phosphate buffer, $\mathrm{pH} 6.8$, containing $100 \mu \mathrm{m}$ EDTA and $1 \mathrm{~mm}$ sodium metabisulfite, and $100 \mu \mathrm{l}$ aliquots were transferred immediately to tubes containing $10 \mu \mathrm{l}$ of 2.5 M perchloric acid on ice. After $30 \mathrm{~min}$, the homogenates were spun at $15,000 \times g$ for $20 \mathrm{~min}$. Tyrosine, tryptophan, dopamine, norepinephrine, serotonin, 3,4-L-dihydroxyphenylalanine (L-dopa), 3-O-methyldihydroxyphenylalanine (3-MD), 3,4-dihydroxyphenylacetic acid (DO PAC), homovanillic acid (HVA), 3-methoxytyramine (3-MT), 5-hydroxytryptophan (5-HTP), and 5-hydroxyindoleacetic acid (5-HIAA) in the supernatants were measured by HPLC, coupled with electrochemical detection as previously described (Jinnah et al., 1992b).

Tyrosine hydroxylase assay. Tyrosine hydroxylase $(\mathrm{TH})$ was measured using three different methods. A two-step modification of the decarboxylase-coupled $\mathrm{CO}_{2}$ trapping method of Waymire et al. (1971) was initially used to screen large numbers of samples. A modification of the method of Nagatsu et al. (1964) was used to determine kinetic parameters for TH. The accumulation of I-dopa in the caudoputamen following administration of the centrally active aromatic amino acid decarboxylase (AADC) inhibitor NSD 1015 was used to measure TH activity in vivo (Carlsson et al., 1972). Protein was measured by the method of Bradford (1976), using bovine serum albumin as a standard.

For the $\mathrm{CO}_{2}$ trapping assay, frozen tissues were disrupted by sonication in 5-10 vol of ice-cold $50 \mathrm{~mm}$ sodium phosphate buffer, $\mathrm{pH} 6.8$, containing $0.2 \%$ Triton $\mathrm{X}-100$ and $5 \mathrm{~mm}$ dithiothreitol. The first step of the assay included $100 \mu \mathrm{M}{ }^{14} \mathrm{C}$-tyrosine, $1 \mathrm{~mm}$ 6-mcthyltctrahydropterin, $1 \mathrm{~mm} \mathrm{Fe}\left(\mathrm{NH}_{4}\right)_{2}\left(\mathrm{SO}_{4}\right)_{2}, 2000 \mathrm{U}$ of catalase, and $1 \mathrm{M}$ potassium phosphate buffer, $\mathrm{pH} 6.0$, in a total volume of 100 $\mu \mathrm{l}$. The reaction was started by adding $50 \mu \mathrm{l}$ of tissue extract to $50 \mu \mathrm{l}$ of reaction substrate and allowed to proceed for $20-25 \mathrm{~min}$ at $37^{\circ} \mathrm{C}$. The second step was initiated by the addition of $150 \mu \mathrm{l}$ of $0.5 \mathrm{M}$ Tris buffer, $\mathrm{pH} 8.0,1.6 \mathrm{~mm}$ 3-iodotyrosine to block further tyrosine hydroxylation, and $1 \mu \mathrm{l}$ of partially purified hog kidney decarboxylase to liberate ${ }^{14} \mathrm{CO}_{2}$ from ${ }^{14} \mathrm{C}$-L-dopa. The ${ }^{14} \mathrm{CO}_{2}$ evolved was trapped using a rubber stopper with a centerwell containing a piece of filter paper containing $100 \mu \mathrm{l}$ of methylbenzethonium hydroxide. The reaction was terminated by the addition of $100 \mu \mathrm{l}$ of $6 \mathrm{~N}$ trichloroacetic acid, followed by a $2 \mathrm{hr}$ incubation to allow complete $\mathrm{CO}_{2}$ trapping. The filters were then transferred to vials containing Ecoscrint and counted on a scintillation counter.

For the measurement of TH kinctics, dissected caudoputamens from normal and HPRT ${ }^{-}$mice were pooled separately and sonicated in $1 \mathrm{ml}$ of ice-cold $50 \mathrm{~mm}$ HEPES buffer, $\mathrm{pH} 6.0$, containing $0.2 \%$ Triton $\mathrm{X}-100$, $10 \mathrm{~mm}$ dithiothreitol, $1 \mathrm{mg} / \mathrm{ml} \mathrm{NSD} 1015$, and $1 \mu \mathrm{M}$ pepstatin $A$. The homogenates were centrifuged at $45,000 \times g$ for $30 \mathrm{~min}$ and $50 \mu \mathrm{l}$ aliquots of supernatant were taken for each assay. The reaction contained $100 \mu \mathrm{M} \mathrm{L}-3,5-{ }^{3} \mathrm{H}$-tyrosine, $0.2 \mathrm{M}$ sodium phosphate buffer, $\mathrm{pH}$ $6.1,2000 \mathrm{U}$ of catalase, $40 \mathrm{~mm}$ ascorbic acid, and varying concentrations of 6-methyltetrahydropterin $(0.1,0.125,0.16,0.25,0.5$, and $1 \mathrm{~mm})$. The apparent $K_{\mathrm{m}}$ and $V_{\max }$ values were calculated from LineweaverBurk plots using a computer program based on Michaelis-Menton kinetics.

For the measurement of TH activity in vivo, unanesthetized animals were given an intraperitoneal injection of $100 \mathrm{mg} / \mathrm{kg}$ of NSD 1015 , with or without $750 \mathrm{mg} / \mathrm{kg} \gamma$-butyrolactone (GBL; Carlsson ct al., 1972). Caudoputamens were dissected 25 min later for measurement of $L$-dopa as described above.

Choline acetyltransferase assay. ChAT was measured by a modification of the method of Fonnum (1975). The reaction mixture contained $0.1 \mathrm{~mm}{ }^{14} \mathrm{C}$-acetyl $\mathrm{CoA}, 0.5 \mathrm{mg} / \mathrm{ml}$ bovine serum albumin, $100 \mu \mathrm{M}$ physostigmine, $2 \mathrm{~mm}$ choline chloride, $9 \mathrm{~mm}$ EDTA, $300 \mathrm{~mm} \mathrm{NaCl}$, and $50 \mathrm{~mm}$ sodium phosphate buffer, $\mathrm{pH} 7.4$, in a total volume of 20 $\mu 1$. The reaction was started by adding $10 \mu \mathrm{l}$ of diluted tissue extract to $10 \mu \mathrm{l}$ of reaction substrate and allowed to proceed for $30 \mathrm{~min}$ at $37^{\circ} \mathrm{C}$. The reaction was terminated by adding $100 \mu \mathrm{l}$ of ice-cold water and placing the tubes on ice. The ${ }^{14} \mathrm{C}$-acetylcholine formed was extracted from the samples with a mixture of $15 \%$ acetonitrile in toluene (by volume) with $0.5 \%$ tetraphenylboron, added to Ecoscint, and counted in a scintillation counter.

Glutamic acid decarboxylase assay. Glutamic acid decarboxylase (GAD) activity was measured by a modification of the $\mathrm{CO}_{2}$ trapping method of Roberts and Simonsen (1963). The final reaction mixture contained $25 \mathrm{~mm}$ unlabeled L-glutamic acid, $0.2 \mu \mathrm{Ci}$ of ${ }^{14} \mathrm{C}$-L-glutamate, $200 \mu \mathrm{M}$ pyridoxal phosphate, and $0.1 \mathrm{M}$ potassium phosphate buffer, $\mathrm{pH} 7.0$, in a total volume of $120 \mu \mathrm{l}$. The ${ }^{14} \mathrm{CO}_{2}$ evolved was trapped using a rubber stopper with a centerwell containing a piece of filter paper containing $100 \mu \mathrm{l}$ of methylbenzethonium hydroxide. The reaction was started by adding $20 \mu \mathrm{l}$ of tissue extract to $100 \mu \mathrm{l}$ of reaction substrate and allowed to proceed for $30 \mathrm{~min}$ at $37^{\circ} \mathrm{C}$. The reaction was terminated by the addition of $100 \mu$ of $6 N$ trichloroacetic acid, followed by a 2 hr incubation to allow complete $\mathrm{CO}_{2}$ trapping. The filters were then transferred to vials containing Ecoscint and counted in a scintillation counter.

Dopamine uptake site autoradiography. Sections were prepared from tissue frozen in isopentane cooled with liquid nitrogen. After preincubating representative sections with 200 III M NaCl in 50 IIn Tris buffer, $\mathrm{pH} 7.0$, for $20 \mathrm{~min}$ at $4^{\circ} \mathrm{C}$ to remove endogenous ligand, the sections were incubated in the same buffer containing $1 \mathrm{nM}{ }^{3} \mathrm{H}-\mathrm{BTCP}$ at a specific activity of $52 \mathrm{Ci} / \mathrm{mmol}$ for $90 \mathrm{~min}$ at $4^{\circ} \mathrm{C}$ (Filloux et al., 1989). Nonspecific binding was determined by including $1 \mu \mathrm{M}$ GBR 12909 in the 

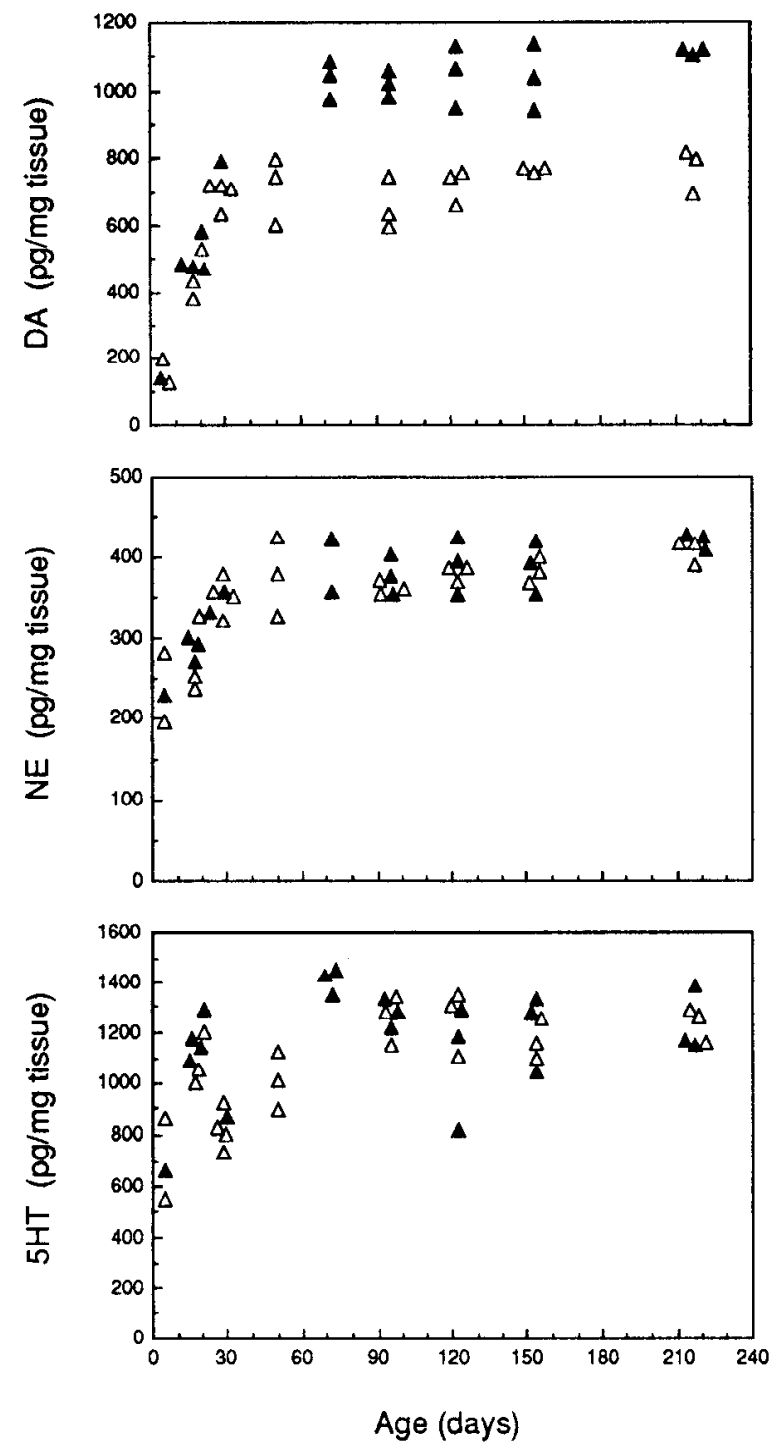

Figure 1. Age-dependent concentrations of monoamines in extracts from whole mouse brains. Monoamines in whole-brain homogenates of male mice of differing ages were measured by HPLC with electrochemical detection. Because of the difficulty in generating large numbers of inice simultaneously for a longitudinal study, animals were culled at random from different litters. Each symbol represents the monoamine concentration in the brain of a single animal. Solid triangles show data for normal animals $(n=21)$, while open triangles show data for HPRT animals $(n=24)$. Although there was extensive overlap in dopamine (DA) concentrations of normal and mutant animals during the first 30 $\mathrm{d}$ of development, there was absolutely no overlap after this time. In contrast, there was extensive overlap in norepinephrine $(N E)$ and 5-HT levels between normal and mutant animals throughout development and aging.

incubation medium of adjacent tissuc sections. Radiolabeling was terminated by rinsing the sections in fresh buffer four times for 8 min each and then drying with cold, desiccated air. The slides were stored in dessicated containers at $4^{\circ} \mathrm{C}$ before being apposed to tritium-sensitive Hyperfilm. Tritium-impregnated Microscale standards (Amersham) were included with the tissues. After $60 \mathrm{~d}$, the film was developed by immersing in Kodak D-19 developer for $5 \mathrm{~min}$, rinsing for $30 \mathrm{sec}$, and then fixing in Kodak Rapidfix for $5 \mathrm{~min}$. Quantitative analysis of relative optical densities was conducted using a microcomputer imaging system (Imaging Research Inc., St. Catherines, Ontario, Canada).

\section{Results}

Age-related changes in whole-brain monoamines. The levels of dopamine, norepinephrine, and 5-HT were compared in whole-
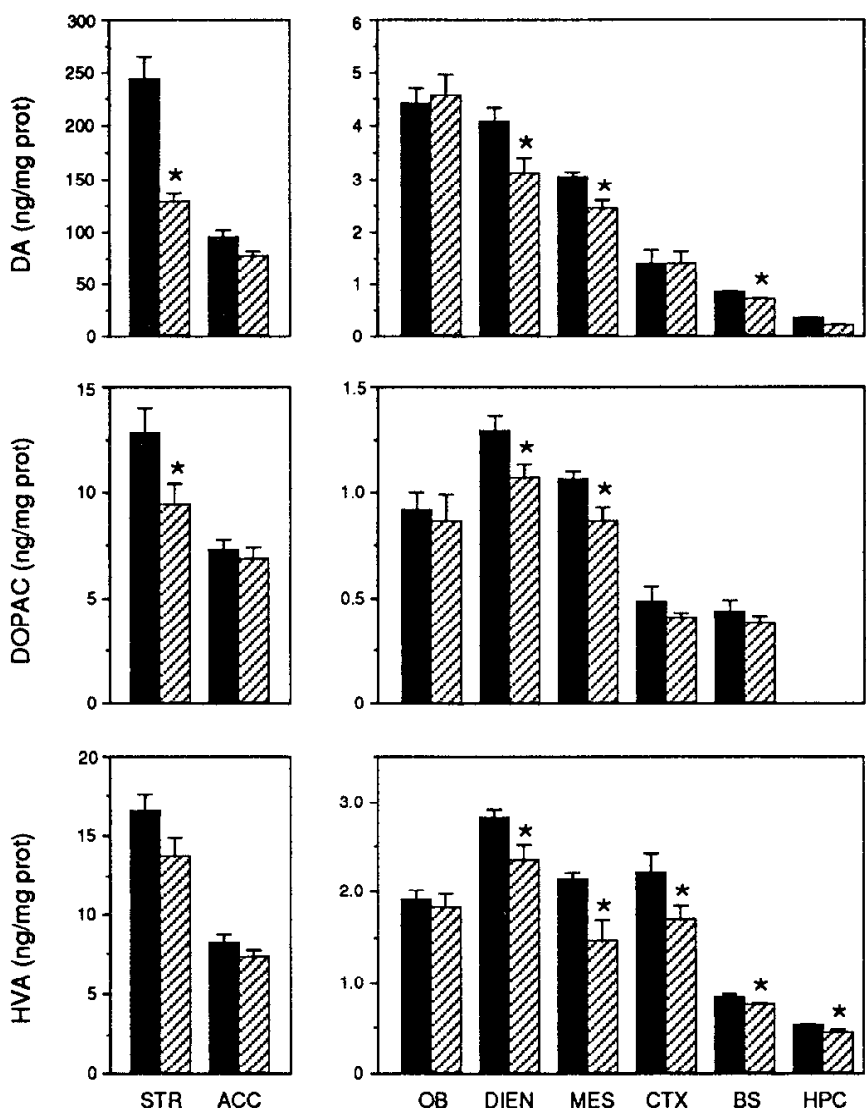

Figure 2. Regional analysis of dopamine, DOPAC, and HVA. Dopamine $(D A)$ and its metabolites DOPAC and HVA were measured in the caudoputamen $(S T R)$, accumbens/olfactory tubercle $(A C C)$, olfactory bulb $(O B)$, diencephalon $(D I E N)$, midbrain $(M E S)$, cortex $(C T X)$, brainstem $(B S)$, and hippocampus $(H P C)$ of 12-week-old HPRT ${ }^{+}$(solid bars, $n=8$ ) and HPRT- (hatched bars, $n=8$ ) male mice. Results show average values in $\mathrm{ng} / \mathrm{mg}$ protein $\pm \mathrm{SE}$. The levels of dopamine, DOPAC, and HVA were below detectable limits in the cerebellum; DOPAC was also below detectable limits in the hippocampus. Statistical analysis was performed on each compound separately by ANOVA with brain region as a repeated measure. For dopamine, statistically significant effects were obscrved for HPRT group $[F(1,14)=31.6, p<0.001]$ and for the interaction of group $\times$ region $[F(6,84)=22.9, p<0.001]$. For DOPAC, statistically significant effects were also observed for HPRT group $[F(1,14)$ $=6.0, p<0.03]$ and for the interaction of group $\times$ region $[F(6,84)=$ $4.0, p<0.002]$. For HVA, statistically significant effects were also observed for HPRT group $[F(1,14)=7.8, p<0.02]$ and for the interaction of group $\times$ region $[F(7,98)=2.1, p<0.05]$. Asterisks $\left(^{*}\right)$ denote significant differences between normal and mutant animals in particular brain regions.

brain homogenates prepared from normal and HPRT ${ }^{-}$mice during development and aging. In normal animals, whole-brain dopamine levels increased from birth until 30-60 d of age (Fig. 1). Afterward, dopamine was maintained at a stable level for

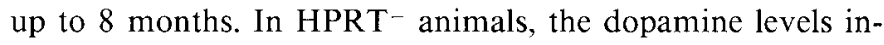
creased from birth until approximately $30 \mathrm{~d}$ of age before reaching stable adult levels. There was considerable overlap in wholebrain dopamine levels in $\mathrm{HPRT}^{+}$and $\mathrm{HPRT}^{-}$mice up to $30 \mathrm{~d}$ of age; after this age, the differential increases in the dopamine levels of normal and mutant animals resulted in the appearance of a $40 \%$ difference in the levels of dopamine in whole-brain extracts of normal and mutant adult mice (Fig. 1).

The levels of norepinephrine and 5-HT also increased during postnatal development in whole-brain homogenates from the mice, reaching stable adult values at approximately $30 \mathrm{~d}$ of age 

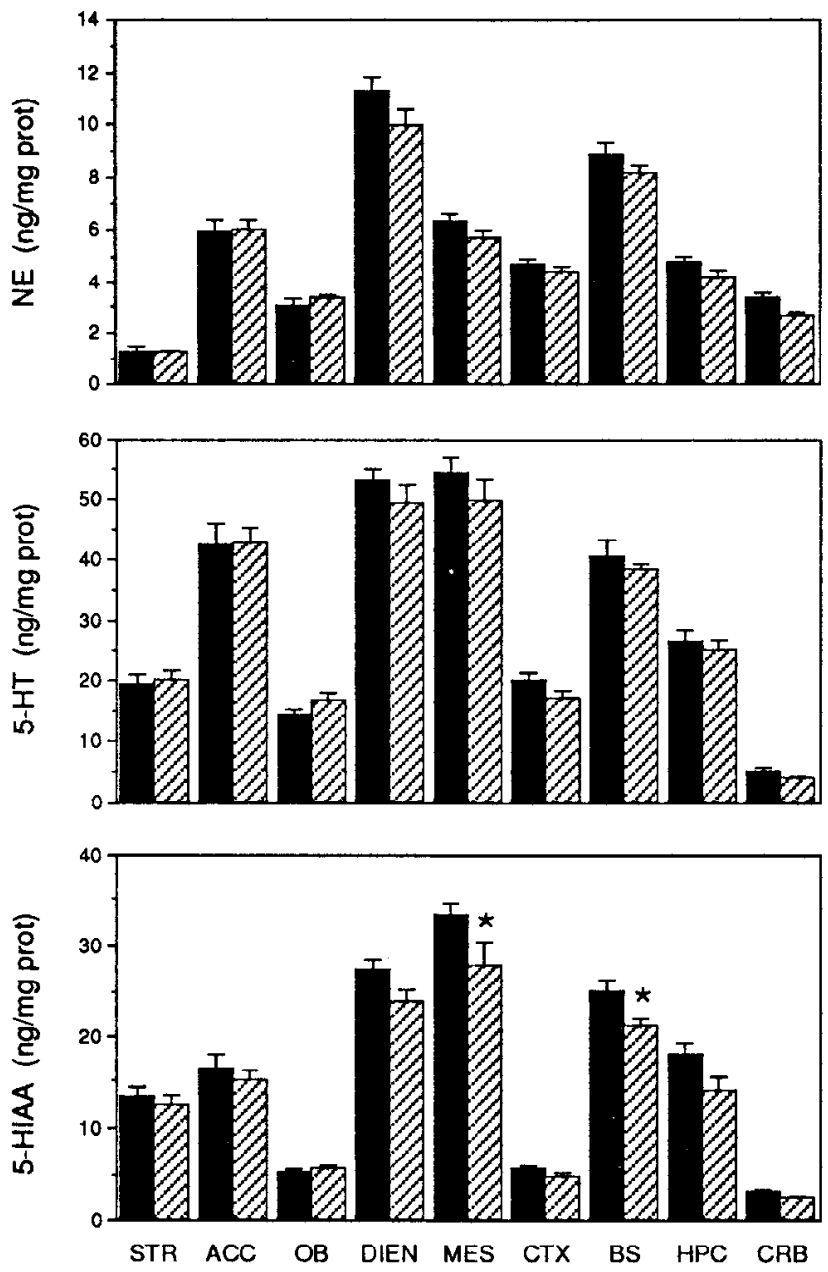

Figure 3. Regional analysis of norepinephrine, 5-HT, and 5-HIAA. Norepinephrine $(N E), 5$-HT, and the 5-HT metabolite 5-HIAA were measured in the caudoputamen (STR), accumbens/olfactory tubercle $(A C C)$, olfactory bulb $(O B)$, diencephalon (DIEN), midbrain (MES), cortex $(C T X)$, brainstem $(B S)$, hippocampus (HPC), and cerebellum $(C R B)$ of 12 -week-old HPRT ${ }^{+}$(solid bars, $n=8$ ) and HPRT- (hatched bars, $n=8$ ) male mice. Results show average values in $\mathrm{ng} / \mathrm{mg}$ protein \pm SE. Statistical analysis was performed on each compound separately by ANOVA with brain region as a repeated measure. For norepinephrine, there was a significant main effect of HPRT group $[F(1,14)=7.1$, $p<0.02]$, but no significant interactive effects of group $\times$ region $[F(8,114)$ $=1.4, p>0.10]$. For 5-HT, there were no statistically significant effects of HPRT group $[F(1,14)=2.7, p>0.10]$ or group $\times$ region interactions $[F(8,112)=0.7, p>0.10]$. For 5 -HIAA, there was a statistically significant effect of HPRT group $[F(1,14)=10.2, p<0.005]$, and a significant interactive effect of group $\times$ region $[F(8,112)=2.1, p<0.05]$. Asterisks $\left(^{*}\right)$ denote significant differences between normal and mutant animals in particular brain regions.

(Fig. 1). In contrast to the reduced levels of dopamine observed in adult HPRT- mice, the levels of norepinephrine and 5-HT in these animals were normal throughout development and aging.

Regional concentrations of monoamines in adult mice. The levels of monoamines in different regions of the brains of 12 week-old animals were examined to determine if the reduction in dopaminc found in whole-brain homogenates of the IIPRT ${ }^{-}$ mice was due to a global reduction of dopamine throughout the brain, or if the deficit was limited to particular subregions. Dopamine levels in normal mice varied considerably among different brain regions, with the highest levels in the caudoputamen

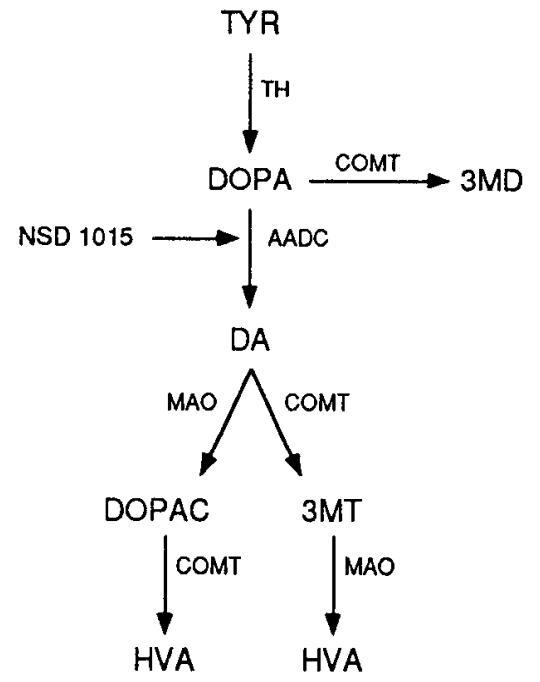

Figure 4. Pathways of brain dopamine metabolism. Tyrosine hydroxylase $(T H)$, the rate-limiting step in the synthesis of dopamine, converts tyrosine $(T Y R)$ to L-dopa in the presence of tetrahydrobiopterin. L-dopa is then converted rapidly to dopamine $(D A)$ by the action of aromatic amino acid decarboxylase $(A A D C)$, an enzyme that is inhibited by the drug $N S D$ 1015. Catechol- $O$-methyltransferase (COMT) converts L-dopa and dopamine to 3-O-methyl-dopa (3MD) and 3-methoxytyramine $(3 M T)$, respectively. $D O P A C$ is produced from dopamine by the action of monoamine oxidase $(M A O)$. Homovanillic acid $(H V A)$ is produced from DOPAC (by the action of COMT) or from 3-MT (by the action of MAO). These pathways have been described in detail previously (Westerink, 1985; Wood and Altar, 1988).

(Fig. 2). In the HPRT ${ }^{-}$mice, dopamine levels were significantly reduced in some, but not all, brain regions. The most pronounced reductions in dopamine levels were observed in the caudoputamen $(-47.5 \%)$. Smaller reductions in dopamine levels were observed in the diencephalon $(-23.7 \%)$, midbrain $(-19.9 \%)$, and brainstem $(-15.5 \%)$. In contrast, the HPRTmice had normal levels of dopamine in the accumbens, olfactory bulbs, and cortex (Fig. 2).

The levels of the dopamine metabolites DOPAC and HVA were also reduced in some, but not all, brain regions from the HPRT $^{-}$mice (Fig. 2). DOPAC levels were significantly reduced in the caudopulamen $(-26.2 \%)$, diencephalon $(-16.5 \%)$, and midbrain $(-18.3 \%)$, but not in other regions. HVA levels were significantly reduced in the diencephalon $(-16.4 \%)$, midbrain $(-31.9 \%)$, cortex $(-23.1 \%)$, and brainstem $(-10.8 \%)$.

In contrast to the decreases in dopamine levels in the HPRT mice, norepinephrine and 5-HT levels appeared relatively normal (Fig. 3). The levels of 5-HIAA also appeared relatively normal; small but significant reductions were observed in the midbrain $(-16.3 \%)$ and brainstem $(-15.6 \%)$ only.

Tyrosine hydroxylation in the caudoputamen. To determinc if the decreased levels of dopamine in the caudoputamen of HPRT $^{-}$mice might be associated with a decrease in the synthesis of dopamine in this region, we examined the activity of $\mathrm{TH}$, the rate-limiting step in the production of dopamine (Fig. 4). TH activity in vivo was measured following the administration of NSD 1015 as previously described (Carlsson et al., 1972). Since this drug causes a complete blockade of brain AADC, it is possible to measure the accumulation of $\mathrm{L}$-dopa as an indirect measurement of tyrosine hydroxylation in vivo. Tyrosine hydroxylation was also measured in the presence of GBL, a drug that increases the synthesis of dopamine by suppressing impulse 

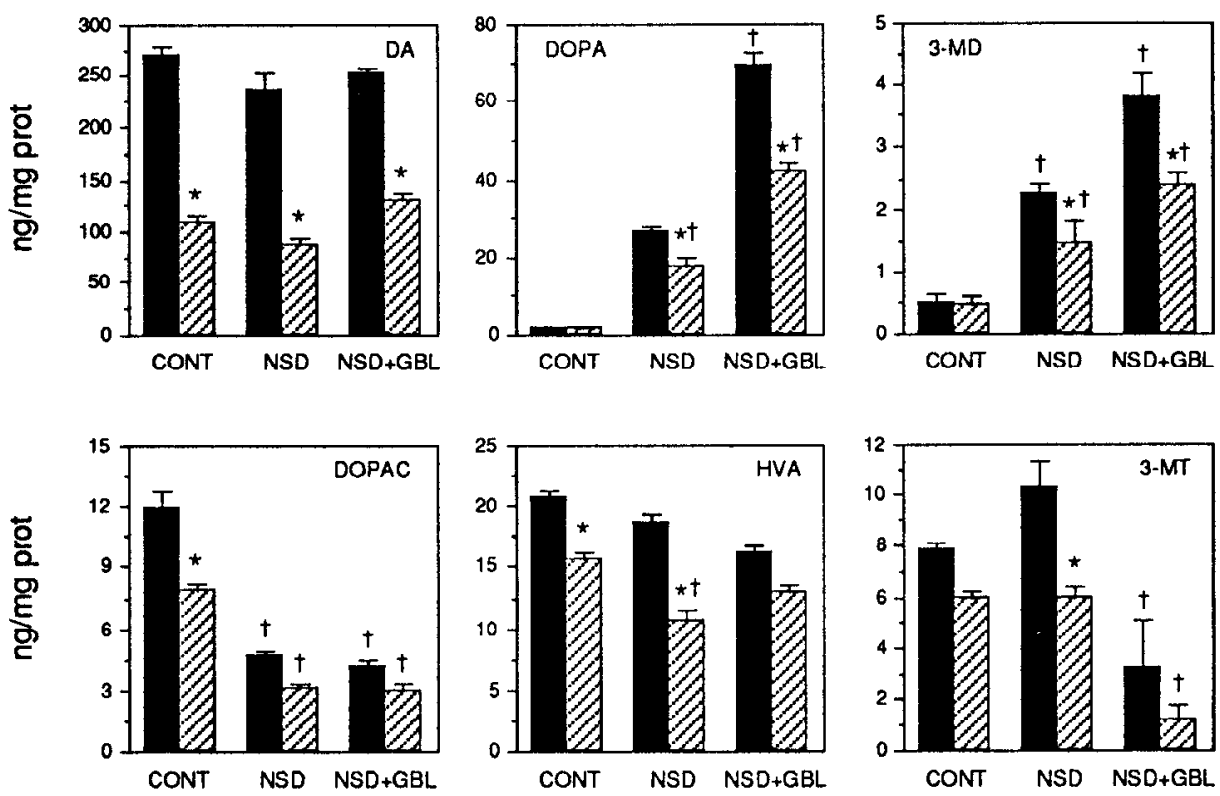

Figure 5. Effects of NSD 1015 on brain dopamine metabolism. L-dopa, 3-MD, dopamine, DOPAC, HVA, and 3-MT were measured in the caudoputamen of $\mathrm{HPRT}^{+}$and HPRT ${ }^{-}$male mice 25 min after treatment with saline, $100 \mathrm{mg} / \mathrm{kg}$ of the decarboxylase inhibitor NSD 1015 , or NSD $1015+$ GBL $(750 \mathrm{mg} / \mathrm{kg}$ ). Results show average values in $\mathrm{ng} / \mathrm{mg}$ protein $\pm \mathrm{SE}$. A total of seven normal mice (solid bars) and seven mutants (hatched bars), all at least 12 weeks of age, were tested under each condition. Statistical analysis was performed using multivariate ANOVA with HPRT group and treatment condition as factors. Significant main effects of HPRT group and treatment condition were observed for each of the metabolites measured $(p<0.001)$. This analysis also revealed statistically significant interactive effects of HPRT $\times$ treatment for each of the metabolites $(p<0.05)$ except dopamine $(p>0.10)$. Univariate ANOVA and Tukey tests were used to compare differences between HPRT ${ }^{+}$and HPRT- mice within treatment groups, and to compare the effects of drug treatments on each metabolite within HPRT group. An asterisk (*) indicates a statistically significant difference between normal and mutant animals within a treatment category $(p<0.05)$. A dagger $(\dagger)$ indicates a statistically significant of the drug treatment in comparison with saline-treated animals of the same HPRT status $(p<0.05)$.

flow and reducing dopamine autoreceptor-mediated feedback inhibition in dopaminergic neurons (Haubrich and Pflueger, 1982; Anden et al., 1983a; Yarbrough et al., 1984). By increasing dopamine synthesis, GBL may amplify any potential differences in dopamine synthesis rates.

The levels of $\mathrm{L}_{\text {-dopa in }}$ untreated HPRT ${ }^{+}$and HPRT ${ }^{-}$mice were similar, although the measurement of small differences was difficult because the concentrations of this compound were near our limit of detection $(0.5 \mathrm{ng} / \mathrm{mg}$ protein). However, $\mathrm{L}$-dopa was readily detected $25 \mathrm{~min}$ after the administration of NSD 1015 (Fig. 5). The L-dopa accumulation in the HPRT ${ }^{-}$mice was $33.4 \%$ lower than in normal mice. Concurrent administration of GBL resulted in an amplification of the accumulation of L-dopa in both normal and mutant animals, but the total levels of $\mathbf{L}$-dopa were, again, $39.8 \%$ lower in the HPRT- mice than in normal animals. The GBL-stimulated increase in L-dopa accumulation was similar in magnitude in $\mathrm{HPRT}^{+}$and $\mathrm{HPRT}^{-}$ mice; relative to animals treated with NSD 1015 alone, the addition of GBL increased $\mathrm{L}$-dopa levels 2.6 -fold in normal mice and 2.4-fold in mutants. Changes in the levels of 3-MD, a metabolite of L-dopa, closely paralleled those of L-dopa (Fig. 5). These results demonstrate that the rate-limiting step in the synthesis of dopamine is impaired in vivo in the HPRT ${ }^{-}$mice.

Consistent with previous results, the levels of dopamine in the HPRT ${ }^{-}$mice were significantly lower than normal in all three treatment groups (Fig. 5). The average decrcases in dopamine levels in HPRT $^{-}$mice were $-59.1 \%,-63.9 \%$, and $-49.1 \%$ in the saline, NSD 1015 , and NSD $1015+$ GBL groups, respectively. Treatment with NSD 1015 alone had an insignif- icant effect on dopamine levels in both normal and mutant animals. In contrast to the reductions in L-dopa and dopamine observed in the HPRT- mice, the levels of tyrosine were normal, with or without drug treatments. The average tyrosine contents of normal and HPRT ${ }^{-}$mice were $262 \pm 7.1$ and $244.6 \pm 12.9$ $\mathrm{ng} / \mathrm{mg}$ protein, respectively. This result indicates that the reduction in dopamine synthesis is not due to substrate limitation.

In this experiment, the levels of DOPAC and HVA were also significantly lower than normal in the HPRT- mice, with or without treatment with NSD 1015 or GBL (Fig. 5). NSD 1015 caused a significant drop in the levels of these metabolites in both normal and mutant animals. The levels of 3-MT were also significantly lower in the HPRT ${ }^{-}$mice. The administration of NSD 1015 had little effect on 3-MT levels, but the administration of NSD 1015 with GBL caused a marked reduction in 3-MT levels in both HPRT $^{+}$and HPRT $^{-}$mice. These effects of GBL on the dopamine metabolites are consistent with its ability to suppress the in vivo release of dopamine by dopaminergic neurons (Anden et al., 1983a,b). When averaged across all treatment groups, the decreases in DOPAC, HVA, and 3-MT levels of the HPRT $^{-}$mice were $-32.2 \%,-28.8 \%$, and $-20.3 \%$, respectively.

Tryptophan hydroxylation in the caudoputamen. The synthesis of 5-H' I involves the hydroxylation of tryptophan to 5-HTP, followed by decarboxylation by AADC to produce 5-HT. Since the administration of NSD 1015 blocks the decarboxylation of 5-HTP as well as L-dopa, it is possible to measure the accumulation of 5-HTP as an indirect measurement of the activity of tryptophan hydroxylase in vivo (Carlsson et al., 1972). The 

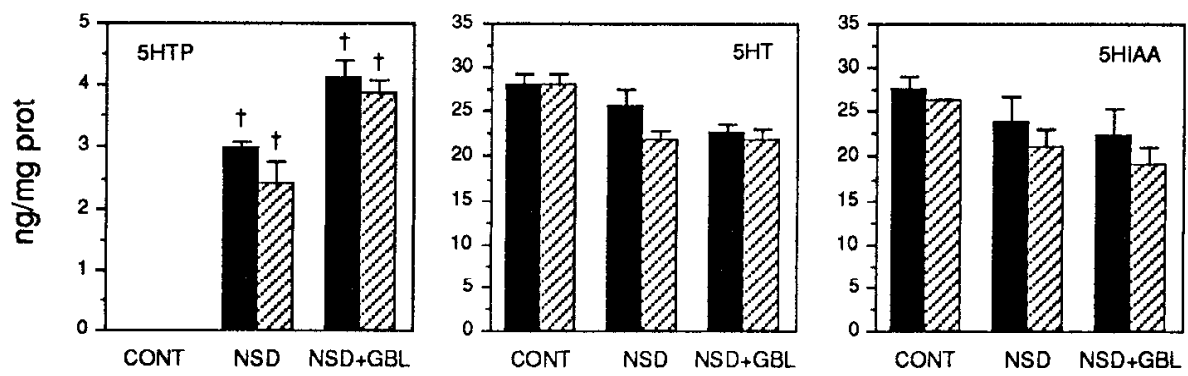

Figure 6. Effects of NSD 1015 on brain serotonin metabolism. 5-HTP, 5-HT, and 5-HIAA were measured in the caudoputamen of HPRT ${ }^{+}$and HPRT - male mice 25 min after treatment with saline, $100 \mathrm{mg} / \mathrm{kg}$ of the decarboxylase inhibitor NSD 1015 , or NSD $1015+$ GBL (750 mg/kg). Results show average values in $\mathrm{ng} / \mathrm{mg}$ protein $\pm \mathrm{SE}$. A total of seven normal mice (solid bars) and seven mutants (hatched bars), all at least 12 weeks of age, were tested under each condition. Statistical analysis was performed using multivariate ANOVA with HPRT group and treatment condition as factors. This analysis revealed a statistically significant main effect of treatment for all threc measures $(p<0.01)$. No significant differences were observed when HPRT was used as a grouping factor, and no significant interactive effect of HPRT group $\times$ treatment condition was observed $(p>0.05)$. A dagger $(\dagger)$ indicates a statistically significant effect of the drug treatment in comparison with saline-treated animals of the same HPRT status $(p<0.05)$.

levels of 5-HTP in untreated animals were below the level of detection in our assay $(0.5 \mathrm{ng} / \mathrm{mg}$ protein). The administration of NSD 1015 caused a significant increase in 5-HTP levels, which was further augmented by GBL in both normal and mutant animals (Fig. 6). In contrast to the reduced accumulation of L-dopa in HPRT- mice treated with NSD 1015, the accumulation of 5-HTP was similar in the brains of $\mathrm{HPRT}^{+}$and HPRT $^{-}$(with or without GBL). The HPRT ${ }^{-}$mice had normal levels of tryptophan, 5-HT, and 5-HIAA. These results demonstrate that tryptophan hydroxylation, the rate-limiting step in the synthesis of 5-HT, is not impaired in the HPRT ${ }^{-}$mice.

In vitro assays for $T H, C h A T$, and $G A D$ in different brain regions. Results obtained after treatment of normal and HPRT ${ }^{-}$ animals with NSD 1015 demonstrate that the reduced dopamine levels in the brains of the HPRT- mice are associated with normal levels of the precursor tyrosine but decreased tyrosine hydroxylation. These results suggest a deficiency in TH enzyme activity in the brains of the HPRT ${ }^{-}$mice. Therefore, different brain regions from normal and mutant animals were dissected for direct in vitro measurements of TH activity (Table 1). TH activity was significantly lower $(-33.1 \%)$ in the caudoputamen of HPRT ${ }^{-}$as compared to normal mice $(p<0.001)$. TH was also significantly decreased in the cortex of the HPRT- mice $(-33.1 \%)$, but not in other regions.

For comparison, the activities of ChAT and GAD were measured in the same tissue homogenates used for the TH assay (Table 1). ChAT activity was slightly but significantly reduced $(-16.4 \%)$ in the caudoputamen of the HPRT ${ }^{-}$mice, but was normal in all other regions. GAD activity was normal in all brain regions from the HPRT- mice, including the caudoputamen. In subsequent experiments with three independent groups of animals, TH activity was consistently found to be reduced by $30-35 \%$ in caudoputamen of the mutants. The reduction in ChAT activity in the caudoputamen of the HPRT ${ }^{-}$mice was also reproducible, but the magnitude of the change was always quite small (10-20\%).

TH encyme kinetics. Since the previously described measurements of TH activity were performed with a single concentration of substrate, it was not possible to determine if the decreases in TH activity were due to reductions in $V_{\max }$ or changes in the affinity of the enzyme for its cofactor. To compare kinetic parameters for caudoputamen TH in normal and mutant ani-
Table 1. Neurotransmitter synthetic enzymes in HPRT ${ }^{+}$and HPRT - mice

\begin{tabular}{|c|c|c|c|}
\hline & $\begin{array}{l}\text { TH } \\
(\mathrm{pmol} / \mathrm{min} / \mathrm{mg})\end{array}$ & $\begin{array}{l}\mathrm{ChAT} \\
(\mathrm{nmol} / \mathrm{min} / \mathrm{mg})\end{array}$ & $\begin{array}{l}\text { GAD } \\
\text { (nmol/ } \\
\mathrm{min} / \mathrm{mg} \text { ) }\end{array}$ \\
\hline \multicolumn{4}{|c|}{ Caudoputamen } \\
\hline HPRT $^{+}$ & $118.91 \pm 5.22$ & $15.25 \pm 0.85$ & $4.40 \pm 0.42$ \\
\hline HPRT $^{-}$ & $79.52 \pm 2.93^{*}$ & $12.75 \pm 0.43^{*}$ & $3.91 \pm 0.19$ \\
\hline \multicolumn{4}{|l|}{ Accumbens } \\
\hline HPRT $^{+}$ & $29.52+3.90$ & $10.11+0.92$ & $9.55 \pm 0.46$ \\
\hline HPRT $^{-}$ & $22.91 \pm 1.81$ & $9.02 \pm 0.31$ & $8.62 \pm 0.34$ \\
\hline \multicolumn{4}{|l|}{ Cortex } \\
\hline $\mathrm{HPRT}^{+}$ & $1.27 \pm 0.85$ & $4.27 \pm 0.21$ & $4.14 \pm 0.20$ \\
\hline HPRT $^{-}$ & $0.85 \pm 0.05^{*}$ & $3.81 \pm 0.13$ & $4.20 \pm 0.28$ \\
\hline \multicolumn{4}{|c|}{ Ilippocampus } \\
\hline $\mathrm{HPRT}^{+}$ & $0.54 \pm 0.07$ & $3.37 \pm 0.14$ & $4.05 \pm 0.16$ \\
\hline HPRT $^{-}$ & $0.45 \pm 0.03$ & $3.29 \pm 0.08$ & $4.32 \pm 0.11$ \\
\hline \multicolumn{4}{|c|}{ Diencephalon } \\
\hline $\mathrm{HPRT}^{+}$ & $2.82 \pm 0.15$ & $3.27 \pm 0.25$ & $9.38 \pm 0.21$ \\
\hline HPRT $^{-}$ & $2.52 \pm 0.14$ & $3.20 \pm 0.22$ & $9.15 \pm 0.12$ \\
\hline \multicolumn{4}{|l|}{ Midbrain } \\
\hline $\mathrm{HPRT}^{+}$ & $2.10 \pm 0.25$ & $3.56 \pm 0.21$ & $9.52 \pm 0.30$ \\
\hline HPRT $^{-}$ & $1.81 \pm 0.12$ & $3.74 \pm 0.12$ & $9.75 \pm 0.16$ \\
\hline \multicolumn{4}{|l|}{ Brainstem } \\
\hline HPRT $^{+}$ & $1.15 \pm 0.27$ & $4.89 \pm 0.96$ & $4.35 \pm 0.11$ \\
\hline HPRT $^{-}$ & $0.93 \pm 0.03$ & $4.84 \pm 0.22$ & $4.51 \pm 0.15$ \\
\hline \multicolumn{4}{|l|}{ Cerebellum } \\
\hline HPRT $^{+}$ & $0.19 \pm 0.01$ & $0.38 \pm 0.06$ & $2.98 \pm 0.16$ \\
\hline $\mathrm{HPRT}^{-}$ & $0.21 \pm 0.04$ & $0.36 \pm 0.02$ & $3.02 \pm 0.12$ \\
\hline
\end{tabular}

Neurotransmitter synthetic enzymes in different brain regions of $\mathrm{HPRT}^{+}(n=5)$ and HPRT $(n=7)$ niale nilice. Results show average values $\pm \mathrm{SE}$ (units/mg protein). Brain regions from 12-week-old adults were dissected rapidly on an icecooled platform and frozen at $-70^{\circ} \mathrm{C}$ prior to assay. Tyrosine hydroxylase $(\mathrm{TH})$, choline acetyltransferase $(\mathrm{Ch} \Lambda \mathrm{T})$, and glutamic acid decarboxylase (GAD) were measured as described in Materials and Methods. The results for each enzyme were examined separately by ANOVA with brain region as a repeated measure. For TH there was a significant main effect of HPRT group $[F(1,10)=36.6, p<$ $0.001]$ and a significant interaction for HPRT $\times$ region $[F(7,70)=43.2, p<$ $0.001]$. For ChAT there was also a significant main effect of HPRT group $[F(1,10)$ $=21.3, p<0.01]$ and significant interaction of HPRT $\times$ region $[F(7,70)=2.9$, $p<0.01]$. For GAD, no significant effect of HPRT group $[F(1,10)=0.5, p>$ $0.10]$ and no significant interaction of HPRT $\times$ region were observed.

* Significant differences between normal and mutant animals in particular brain regions $(p<0.05)$. 
Figure 7. Kinetic analysis of TH in the caudoputamen of $\mathrm{HPRT}^{+}$(solid circles, $n=6$ ) and HPRT- (open circles. $n=6$ ) mice. TH activity in tissue homogenates was measured in the presence of varying amounts of the 6-methyltetrahydropterin cofactor. This analysis indicated $V_{\max }$ values of 1.19 and $0.66 \mathrm{nmol} / \mathrm{min} / \mathrm{mg}$ for HPRT ${ }^{+}$and HPRT $^{-}$mice, respectively. $K_{\mathrm{m}}$ values were 507 and 245 for the HPRT $^{+}$and HPRT $^{-}$mice, respectively. Thus, the maximal enzyme velocity was reduced by $45 \%$ but the affinity for the pterin cofactor was increased. Data from nor$\mathrm{mal}$ and mutant mice were fit to independent regression lines (correlation coefficients $>0.99)$ with significantly different slopes $(p<0.001)$ and y-intercepts $(p<0.001)$.

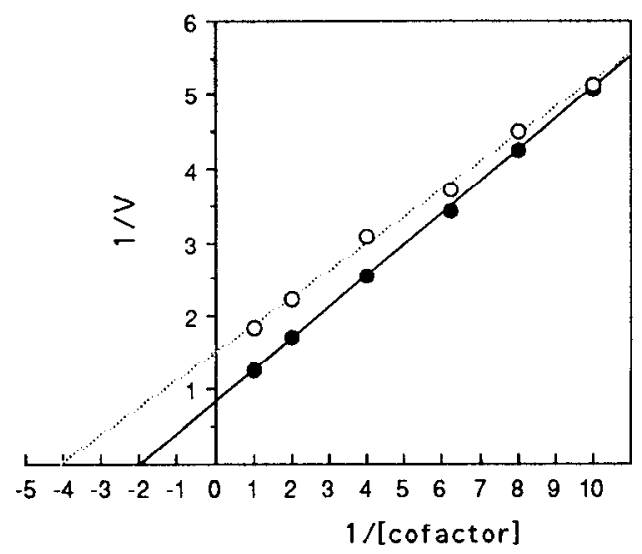

\begin{tabular}{lcc}
\hline & HPRT & O HPRT \\
\hline$V_{\max }$ & 1.19 & 0.66 \\
$\mathrm{Km}$ & 507 & 245 \\
\hline
\end{tabular}

mals, we conducted $\mathrm{TH}$ assays with varying concentrations of the 6-methyltetrahydropterin cofactor. Reverse reciprocal plots of TH activity versus cofactor concentration demonstrated that caudoputamen TH from the HPRT ${ }^{-}$animals had a $V_{\max }$ that was $45 \%$ lower than in normal animals, but an increased affinity for the pterin cofactor (Fig. 7). These results confirm the decrease in maximal caudoputamen TH activity in the HPRT ${ }^{-}$mice, and demonstrate additional changes in its regulatory properties.

TH immunohistochemistry. The most obvious explanation for the reductions in dopamine and $\mathrm{TH}$ in the caudoputamen of the HPRT ${ }^{-}$mice is a loss of midbrain dopamine neurons or a reduction in dopamine fiber projections to the caudoputamen. These possibilities were examined using anatomical techniques. Nissl stains of serial sections spaced at $100 \mu \mathrm{m}$ intervals throughout the brain failed to reveal any obvious neuroanatomical abnormalities in the HPRT ${ }^{-}$mice. Regional morphology and cell densities appeared grossly normal in all brain regions. In particular, there was no evidence for loss of neurons in the midbrain (not shown). Immunohistochemical labeling of TH in serial sections from the brains of normal and mutant animals also demonstrated no obvious abnormalities in the distribution or density of TH-positive elements in the brains of the HPRTmice (Fig. 8). Labeling of midbrain dopamine neurons by in situ hybridization methods also failed to reveal any obvious loss of neurons (not shown).

Quantitative autoradiography of dopamine uptake sites in the caudoputamen. We used quantitative autoradiography to measure the binding of ${ }^{3} \mathrm{H}$-BTCP to dopamine uptake sites as an indirect measure of dopamine fiber density in the basal ganglia of normal and HPRT ${ }^{-}$mice (Filloux et al., 1989). Binding of ${ }^{3} \mathrm{H}-\mathrm{BTCP}$ in the HPRT- mice was lower than that of normal animals in all three forebrain regions examined (Fig. 9). In particular, ${ }^{3} \mathrm{H}-\mathrm{BTCP}$ binding was reduced by $25 \%$ in the caudoputamen of the mutant mice.

\section{Discussion}

Although the HPRT ${ }^{-}$mice do not exhibit any obvious neurobehavioral abnormalities, neurochemical analysis clearly indicates that their brains are not entirely normal. HPRT deficiency in the mouse does not produce global neurochemical deficits, despite the fact that HPRT is expressed in all brain cells as a so-called "housekeeping" enzyme (Jinnah et al., 1992a). The dopamine systems are selectively vulnerable in the HPRT- mice while the noradrenergic, serotonergic, GABAergic, and cholinergic systems appear spared. The abnormalities of the dopamine systems in the brains of these mice are also regionally selective in that the most severe deficits occur in the caudoputamen, while other regions are normal or less severely affected. The reduction in dopamine levels in the brains of the HPRT ${ }^{-}$mice is analogous to that reported for patients with Lesch-Nyhan disease (Lloyd et al., 1981), and the observation that reduced basal ganglia dopamine levels are associated with HPRT deficiency in both mouse and man indicates an important role for this enzyme in normal basal ganglia dopamine function.

Basis of the dopamine deficit. The availability of the HPRTmice allowed us to address potential defects underlying the dopamine defect. The decrease in caudoputamen dopamine in the $\mathrm{HPRT}^{-}$mice was accompanied by a decrease in $\mathrm{TH}$, the ratelimiting step in the synthesis of dopamine. These results suggest that a decrease in dopamine synthesis is at least partly responsible for the decreased levels of dopamine. At the biochemical level, a decrease in TII activity in vivo could result from decreased availability of tyrosine as a substrate, a decreased availability of the pterin cofactor, regulatory changes that decrease the specific activity of $\mathrm{TH}$, or a decrease in the number of $\mathrm{TH}$ enzyme molecules present. The presence of normal levels of tyrosine in the brains of the HPRT- mice argues against substrate limitation as a cause for reduced TH activity. Further in vitro kinetic studies of caudoputamen $\mathrm{TH}$ from the HPRT ${ }^{-}$mice indicated that the decreased activity was due to a reduction in maximal enzyme velocity with an increased affinity for its pterin cofactor. These results are consistent with the interpretation that the caudoputamen of the HPRT- mice has fewer TH enzyme molecules with a compensatory upregulation in the specific activity of the remaining $\mathrm{TH}$ molecules. It is unlikely that these changes in ' $\mathrm{H} H$ activity result from a direct effect of the HPRT mutation on the TH enzyme or a second mutation in the TH gene. We believe these changes to be a secondary effect of a neurophysiologic abnormality in the mesotelencephalic dopamine neuron systems resulting from the absence of HPRT. Changes in the regulatory properties of $\mathrm{TH}$ similar to those described in the current studies have been observed in previous studies and appear to result from phosphorylation of the enzyme at a number of different sites (Goldstein and Greene, 1987).

At the anatomic level, the reduction of caudoputamen TH could be due to a loss in the number of TH-containing midbrain dopamine neurons and/or a reduction in $\mathrm{TH}$-containing fibers extending to the caudoputamen. The integrity of midbrain dopamine neurons was evaluated with a combination of Nissl stains, TH immunohistochemistry, and TH in situ hybridiza- 

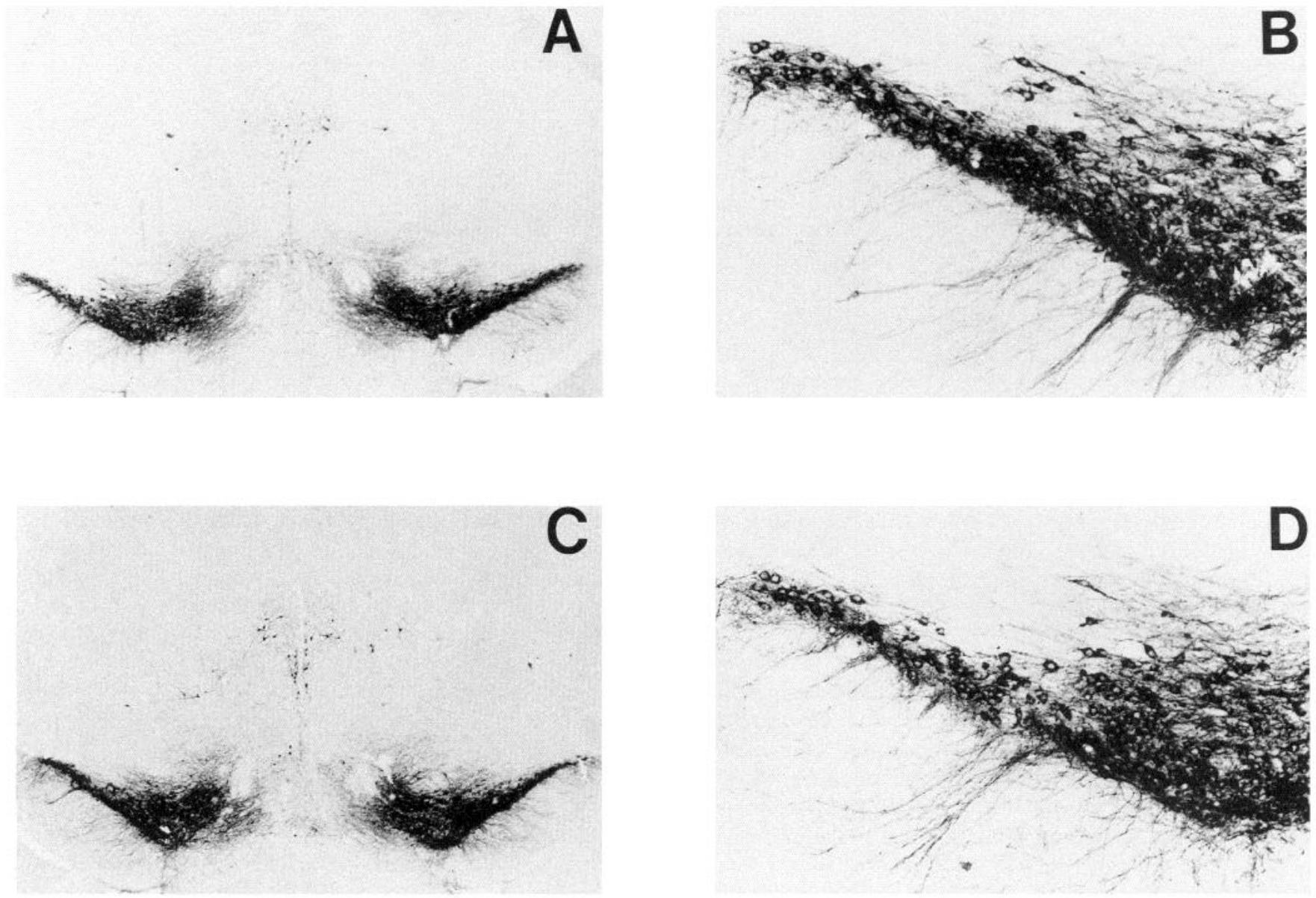

Figure 8. Immunohistochemical labeling of TH neurons in the midbrain of HPRT ${ }^{+}$and $\mathrm{HPRT}^{-}$mice. Sections of formaldehyde fixed tissue (25 $\mu \mathrm{m})$ cut at $100 \mu \mathrm{m}$ intervals through the midbrain of 12-week-old male animals were immunohistochemically stained for TH using the ABC method. Although stained cells were not counted, there was no obvious loss of TH-positive cells in the midbrain of the mutant animals. Results from normal animals are shown in $A$ (low power) and $B$ (high power). Results from HPRT- animals are shown in $C$ and $D$.

tion. These studies failed to provide any evidence for loss of TH-positive midbrain neurons in the HPRT ${ }^{-}$mice, consistent with a previous study (Finger et al., 1988). The density of dopamine fibers in the caudoputamen was estimated by measuring the binding of ${ }^{3} \mathrm{H}$-BTCP to dopamine uptake sites located on the dopamine fibers (Filloux et al., 1989). The quantification of dopamine uptake sites has been used previously as an indirect measure of dopamine fiber density (Roffler-Tarlov et al., 1990; Richter et al., 1992; Simon and Ghetti, 1992) and is preferable to TH immunohistochemistry because enzyme-amplified immunohistochemical procedures may be unreliable for the quantitation of small differences in dopamine fiber density in the caudoputamen (Raisman-Vozari et al., 1991). The results indicated a significant reduction in ${ }^{3} \mathrm{H}-\mathrm{BTCP}$ binding in the caudoputamen of the HPRT ${ }^{-}$mice. These results suggest the presence of normal numbers of midbrain dopamine neurons that have a reduced density of dopamine fibers extending to the caudoputamen. The hypothesis that HPRT- mice have normal midbrain dopamine neurons with reduced extension of fibers to the caudoputamen is supported by biochemical results showing that $\mathrm{TH}$ and dopamine are more significantly reduced in the caudoputamen than in the midbrain.

The role of development. As noted above, the dopamine deficits in the HPRT ${ }^{-}$mice are age dependent and emerge between 30 and $60 \mathrm{~d}$ of postnatal development, a time that parallels several important changes in the development of the dopamine

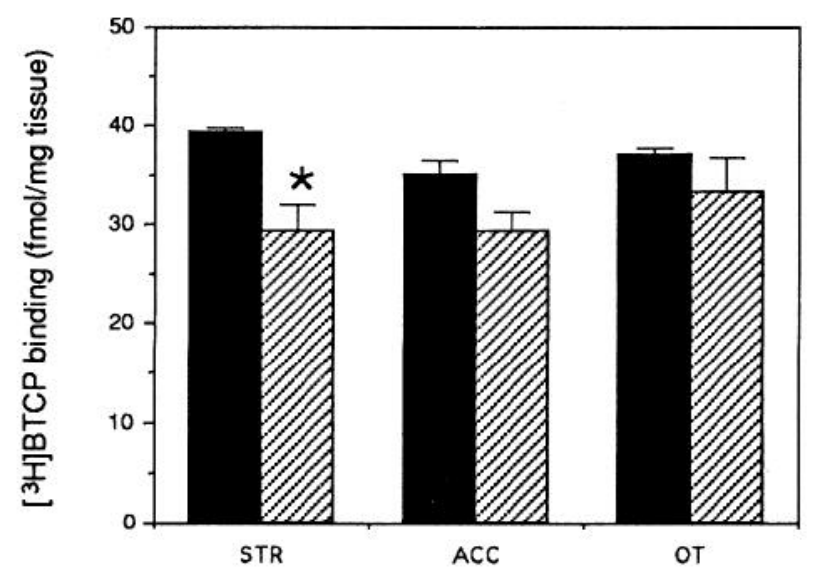

Figure 9. Quantitative analysis of forebrain dopamine uptake sites using ${ }^{3} \mathrm{H}-\mathrm{BTCP}$. The density of binding was determined from exposed films and standards with the aid of a microcomputer-linked image analysis system. Results show average values \pm SE obtained from six normal (solid bars) and six HPRT- (hatched bars) mice. The data were analyzed by two-way ANOVA with brain region as a repeated measure. This analysis showed a significant main effect for HPRT status $[F(1,8)=$ $7.25, p<0.05]$. The main effect for brain region and the interactive effect of HPRT status $\times$ brain region were not statistically significant. A $t$ test for a priori orthogonal contrasts revealed a significant difference in ${ }^{3} \mathrm{H}-\mathrm{BTCP}$ binding between normal and HPRT ${ }^{-}$mice in the caudoputamen $(S T R ; t=2.38, p<0.05)$, but not in the accumbens $(A C C)$ or olfactory tubercle $(O T)$. 
system. In the first 2 weeks of postnatal development in normal rats and mice, dopamine-containing fibers appear localized in discrete patches or "islands" throughout the caudoputamen. In the next few weeks, additional dopamine-containing fibers begin to fill in the gaps or "matrix" to produce the relatively homogeneous pattern of staining observed in the adult (Roffler-Tarlov and Graybiel, 1987; Voorn et al., 1988). The appearance of normal levels of dopamine in the brains of the HPRT- mice prior to day 30 suggests the intriguing possibility that the deficit occurs as the result of a failure of the second stage of dopamine fiber development, that of matrix innervation. Alternatively, the HPRT ${ }^{-}$mice may suffer from metabolic derangements or failed maturation of synaptic specializations in the caudoputamen.

As pointed out in previous studies, it is difficult to separate the potential effects of abnormal development from early degenerative processes through biochemical analysis of brain homogenates (Roffler-Tarlov and Graybiel, 1987). A detailed neuroanatomical analysis of the development of forebrain dopamine fibers in the HPRT ${ }^{-}$mouse will be required to address this issue fully. However, the absence of a progressive decrease in dopamine levels during aging argues against the existence of a continuing degenerative process in the HPRT ${ }^{-}$mice.

Mechanisms by which HPRT deficiency causes the dopamine deficit. These studies raise an important question: how does HPRT deficiency lead to the relatively selective abnormalities of brain dopamine systems? Since there is no known direct biochemical connection between the functions of HPRT and brain dopamine systems, it seems likely that the abnormalities of the dopamine systems in HPRT- mice and Lesch-Nyhan patients are an indirect effect of a disturbance in purine metabolism. HPRT plays a critical role in the salvage pathway for purines, recycling free hypoxanthine and guanine into their respective nucleotides. In principle, an impairment of purine recycling could result in the depletion of some essential purinergic compound during development. Alternatively, degeneration of dopaminergic fibers could result from the buildup of a toxic purine metabolite. However, we have found no evidence for purine depletion or the accumulation of a toxic purine metabolite in the HPRT ${ }^{-}$mice (Jinnah et al., 1993). In addition, global purine depletion in the brain and/or the production of a diffusible toxic metabolite seem inconsistent with the neuroanatomically and neurochemically specific deficits of the basal ganglia dopamine systems observed in the HPRT- mice. Any hypothesis concerning the mechanism responsible for the neurochemical abnormalities must take into account the selective vulnerability of basal ganglia dopamine systems.

Comparison to previous studies. Using different HPRT- mouse strains, previous investigators have also noted neurochemical abnormalities in the brain (Finger et al., 1988; Dunnett and Sirinathsinghji, 1989; Williamson ct al., 1991). However, our results differ from the previous studies in several important respects. In the earlier studies, small reductions in dopamine levels $(-19 \%$ to $-30 \%)$ were observed in most brain regions of the HPRT- mice. Global reductions of dopamine levels in all brain regions were not observed in the present study. Our study revealed large reductions in dopamine levels in the caudoputamen $(-48 \%$ to $-64 \%)$, while other regions were unaffected (e.g., olfactory bulb). The previous studies also described normal levels of the dopamine metabolites DOPAC and HVA in all brain regions. In our studies, small but statistically significant reductions in striatal DOPAC, HVA, and 3-MT were observed in four independent groups of animals. Finally, the previous studies described decreases in brain 5-HT levels, whereas we did not observe significant abnormalities in 5-HT levels or tryptophan hydroxylase activity.

The reasons for the differences between our results and the previous studies are unclear, but may be due to a number of methodological issues. The earlier studies were conducted with a mouse strain genetically unrelated to the one used in this study (Finger et al., 1988; Dunnett and Sirinathsinghji, 1989). The mice also carry a different mutation in the HPRT gene, which was produced by infecting embryonal stem cells with high ratios of retroviral vector to target cell (Kuehn et al., 1987). Thus, the neurochemical deficits in earlier studies may be influenced by the genetic background of the mouse strain, the nature of the mutation, or additional retroviral insertions in other genes. Another explanation is provided by the results in Figure 1, showing that the age of the animals is an important variable affecting the severity of the dopamine deficit in HPRT- mice. Although the ages of the mice used in one study were not reported (Finger et al., 1988), the mice used in the second study were only 8 weeks of age (Dunnett and Sirinathsinghji, 1989). Because of the age-related changes in dopamine levels in normal and mutant mice, we restricted our studies to animals at least 12 weeks of age.

A deficiency in brain dopamine has also been described for the weaver mouse, a mutant unrelated to the HPRT ${ }^{-}$mouse (Schmidt et al., 1982; Roffler-Tarlov and Graybiel, 1984, 1987). Both mutants have a depletion of brain dopamine that is more severe in the caudoputamen than in other regions. Despite the neurochemical similarity, there are a number of important difference between these mutants. For example, the decrease in basal ganglia dopamine in weaver mice is associated with a significant loss of midbrain dopamine neurons (Schmidt et al., 1982; Roffler-Tarlov and Graybiel, 1984, 1987; Gupta et al., 1987; Triarhou et al., 1988; Graybicl et al., 1990), whereas midbrain dopamine neurons appear to be preserved in the HPRT- mice. In addition to the loss of midbrain dopamine neurons, the weaver cerebellum demonstrates abnormal migration and loss of granule cells as well as marked increases in 5-HT content (Schmidt et al., 1982; Hatten et al., 1986). In contrast, the HPRT- mouse cerebellum appears structurally and chemically intact. Weaver mice also display several abnormal behaviors such as ataxia and hindlimb grasping reflexes (Lalonde, 1987; Triarhou and Ghetti, 1987) that are not observed in the HPRT- mice (Finger et al., 1988; Jinnah et al., 1991, 1992b). Although there are some phenotypic similarities to olivocerebellopontine atrophy of humans (Chou et al., 1991), the weaver mouse is not commonly accepted as an animal model for a specific human disease. The HPRT ${ }^{-}$mouse, on the other hand, was produced as a genetically homologous animal model for Lesch-Nyhan disease. Perhaps the most significant difference between the weaver and HPRT- mutants is that the molecular mutation and gene product(s) responsible for the weaver phenotype are unknown. By comparison, the mutation and functions of the gene product in the HPRT ${ }^{-}$mouse have been well characterized, providing obvious leads for further pathogenetic studies.

Relevance to Lesch-Nyhan disease. As previously noted, there are several genetically homologous mouse models of human neurngenetic diseases that have phenotypes differing considerably from their human counterparts. Because normal mice and humans have dissimilar biologies, it should not be surprising 
Table 2. Phenotypic similarities in Lesch-Nyhan disease and the HPRT- mice

\begin{tabular}{lll} 
Feature & LND & HPRT ${ }^{-}$mousc \\
\hline $\begin{array}{l}\text { Molecular level } \\
\text { HPRT gene }\end{array}$ & Multiple mutations & Two mutations \\
HPRT mRNA & Multiple mutations & Undetectable levels \\
Biochemical level & $<1-2 \%$ & $<0.5 \%$ \\
HPRT activity & $\uparrow 5-10-$ fold & $\uparrow 4-5$-fold \\
Purine synthesis & $\downarrow 70-90 \%$ & $\downarrow 40-60 \%$ \\
Dopamine & $\downarrow 60-70 \%$ & $\downarrow 10-20 \%$ \\
ChAT & Normal & Normal \\
Other monoamines & & \\
Anatomical level & None & None \\
Gross anatomical defects & Unknown & Normal \\
Midbrain dopamine neurons & Reduced & Reduced \\
Forebrain dopamine fibers & & \\
Behavioral level & Yes & No \\
Self-injurious behavior & Yes & No \\
Dystonia & Yes & No \\
Choreoathetosis & Ycs & Unknown \\
Mental retardation & & \\
\hline
\end{tabular}

that the pathophysiologic consequences of the same genetic defect may lead to differences in the final phenotype in mouse and man. The phenotype presented by the model will determine which elements of the disease process will be amenable for study using the model; the absence of a perfect phenocopy does not necessarily mean that the model is not useful.

Although the lack of neurobehavioral abnormalities in the HPRT ${ }^{-}$mice similar to those observed in Lesch-Nyhan disease is disappointing, the reduction in dopamine levels in the brains of the HPRT ${ }^{-}$mice is strikingly similar to that reported for patients with Lesch-Nyhan disease. However, the HPRT- mice appear less severely affected than their human counterparts. Dopamine levels are reduced by $70-90 \%$ in Lesch-Nyhan patients (Lloyd et al., 1981), but only by $48-64 \%$ in the HPRT ${ }^{-}$ mice. Although the dopamine deficit appears to be less severe in the mouse than in the human, it is important to note that the absolute magnitude of the deficit is less important than the questions it allows to be addressed. For example, our anatomical studies in the HPRT ${ }^{-}$mice suggest that the dopamine deficit is due to a reduction in dopamine fiber arborization in the caudoputamen, possibly the consequence of impaired development. In fact, positron emission scans in Lesch-Nyhan patients, using a probe that binds to the dopamine transporter, have recently confirmed the existence of a similar defect in dopamine fiber density in the Lesch-Nyhan brain (Harris and Wong, personal communication). The phenotypic elements of Lesch-Nyhan disease and those so far identified in the $\mathrm{HPRT}^{-}$mice are compared in Table 2.

The value of an animal model of a human neurologic disease lies not in how much it can be made to resemble superficially its human counterpart, but in how it can be used to reveal the workings of the normal and abnormal brain. The abnormalities of brain dopamine systems in the HPRT- mice provide an invaluable tool for studying the pathophysiologic mechanisms responsible for the dopamine abnormalities, and the relevance of these abnormalities to the Lesch-Nyhan phenotype. In addition, these mutants provide a new window on how a single gene (or its absence) can result in dysfunction of basal ganglia dopamine systems.

\section{References}

Anden NE, Grabowska M, Liljenberg B (1983a) Demonstration of autoreceptors on dopamine neurons in different brain regions of rats treated with gammabutyrolactone. J Neural Transm 58:143-152.

Anden NE, Grabowska-Anden M, Lindgren S, Thornstrom U (1983b) Synthesis rate of dopamine: difference between corpus striatum and limbic system as a possible explanation of variations in reactions to drugs. Naunyn Schmiedebergs Arch Pharmacol 323:193-198.

Birkenmeier EH, Davisson MT, Beamer WG, Ganschow RE, Vogler CA, Gwynn B, Lyford KA, Maltais LM, Wawrzyniak CJ (1988) Murine mucopolysaccharidosis type VII: characterization of a mouse with B-glucuronidase deficiency. J Clin Invest 83:1258-1266.

Bradford MM (1976) A rapid and sensitive method for the quantitation of microgram quantities of protein utilizing the principle of protein-dye binding. Anal Biochem 72:248-254.

Carlsson A, Davis JN, Kehr W, Lindqvist M, Atack CV (1972) Simultaneous measurement of tyrosine and tryptophan hydroxylase activities in brain in vivo using an inhibitor of the aromatic amino acid decarboxylase. Naunyn Schmiedebergs Arch Pharmacol 275: 153-168.

Chou H, Ogawa N, Asanuma M, Hirata H, Mori A (1991) Dopamine deficiency in the weaver mutant mouse: an animal model of olivopontocerebellar atrophy. Res Commun Chem Pathol Pharmacol 74: $117-120$.

Christie R, Bay C, Kaufman IA, Bakay B, Borden M, Nyhan WL (1982) Lesch-Nyhan disease: clinical experience with nineteen patients. Dev Med Child Neurol 24:293-306.

Darling SM, Abbott CM (1992) Mouse models of human single gene disorders. I: Non-transgenic mice. Bioessays 14:359-366.

Dunn JF, Bannister N, Kemp GJ, Publicover SJ (1993) Sodium is elevated in $m d x$ muscle: ionic interactions in dystrophic cells. J Neurol Sci 114:76-80.

Dunnett SB, Sirinathsinghji DJS (1989) Monoamine deficiency in a transgenic (Hprt-) mouse model of Lesch-Nyhan syndrome. Brain Res 501:401-406.

Emmerson BT, Thompson L (1973) The spectrum of hypoxanthineguanine phosphoribosyltranferase deficiency. Q J Med 166:423-440.

Epstein DJ, Vekemans M, Gros P (1991) Splotch $\left(\mathrm{sp}^{2 \mathrm{H}}\right)$, a mutation affecting development of the mouse neural tube, shows a deletion within the paired homeodomain of Pax-3. Cell 67:767-774. 
Erickson RP (1989) Why isn't a mouse more like a man? Trends Genet $5: 1-3$.

Filloux F, Hunt MA, Wamsley JK (1989) Localization of the dopa mine uptake complex using $\left[{ }^{3} \mathrm{H}\right] N-[1-(2-$ benzo(b)thiophenyl)cyclohexyl]piperidine $\left(\left[{ }^{3} \mathrm{H}\right] \mathrm{BTCP}\right)$ in rat brain. Neurosci Lett 100 : 105-110.

Finger S, Heavens RP, Sirinathsinghji DJS, Kuehn MR, Dunnett SB (1988) Behavioral and neurochemical evaluation of a transgenic mouse model of Lesch-Nyhan syndrome. J Neurol Sci 86:203-213.

Fisher RS (1989) Animal models of the epilepsies. Brain Res Rev 14: 245-278.

Fong P, Turner PR, Denetclaw WF, Steinhardt RA (1990) Increased activity of calcium leak channels in myotubes of Duchenne human and $m d x$ mouse origin. Science 250:673-676.

Fonnum $F$ (1975) A rapid radiochemical method for the determination of choline acetyltransferase. J Neurochem 24:407-409.

Goldstein M, Greene LA (1987) Activation of tyrosine hydroxylase by phosphorylation. In: Psychopharmacology: the third generation of progress (Meltzer HY, ed), pp 75-80. New York: Raven.

Graybiel AM, Ohta K, Romer-Tarlov S (1990) Patteris of cell and fiber vulnerability in the mesostriatal system of the mutant mouse weaver. I. Gradients and compartments. I Neurosci 10:720-733.

Gupta M, Felten DL, Ghetti B (198\%) Selective loss of monoaminergic neurons in weaver mutant mice - an immunocytochemical study. Brain Res 402:379-382.

Hatten ME, Liem RKH, Mason CA (1986) Weaver mouse cerebellar granule neurons fail to migrate on wild-type astroglial processes in vitro. J Neurol Sci 6:2676-2683.

Haubrich DR, Pflueger AB (1982) The autoreceptor control of dopamine synthesis: an in vitro and in vivo comparison of dopamine agonists. Mol Pharmacol 21:114 120.

Hoffman EP, Brown RH, Kunkel LM (1987) Dystrophin: the protein product of the Duchenne muscular dystrophy locus. Cell 51:919-928.

Hooper M, Hardy K, Handyside A, Hunter S, Monk M (1987) HPRTdeficient (Lesch-Nyhan) mouse embryos derived from germline colonization by cultured cells. Nature 326:292-295.

Jaenisch R (1988) Transgenic animals. Science 240:1468-1474.

Jankovic J, Caskey CT, Stout JT, Butler IJ (1988) Lesch-Nyhan syndrome: a study of motor behavior and cerebrospinal fluid neurotransmitters. Ann Neurol 23:466-469.

Jinnah HA, Gage FH, Friedmann T (1991) Amphetamine-induced hehavioral phenotype in a hypoxanthine-guanine phosphoribosyltransferase-deficient mouse model of Lesch-Nyhan syndrome. Behav Neurosci 105:1004-1012.

Jinnah HA, Hess EJ, Wilson MC, Gage FH, Friedmann T (1992a) Localization of hypoxanthine-guanine phosphoribosyltransferase mRNA in the mouse brain by in situ hybridization. Mol Cell Neurosci 3:64-78.

Jinnah HA, Langlais PJ, Friedmann T (1992b) Functional analysis of brain dopamine systems in a genetic mouse model of Lesch-Nyhan syndrome. J Pharmacol Exp i her 263:596-607.

Jinnah HA, Page T, Friedmann T (1993) Brain purines in a genetic mouse model of Lesch-Nyhan disease. J Neurochem 60:2036-2045.

Kelley WN, Wyngaarden JB (1983) Clinical syndromes associated with hypoxanthine-guanine phosphoribosyltransferase deficiency. In: The metabolic basis of inherited disease (Stanbury IB, Wyngaarden JB, Fredrickson DS, Goldstein JL, Brown MS, eds), pp 1115-1143. New York: McGraw-Hill.

Kobayashi T, Yamanaka T, Jacobs JM, Teixeira F, Suzuki K (1980) The Twitcher mouse: an enzymatically authentic model of human globoid cell leukodystrophy (Krabbe disease). Brain Res 202:479483.

Kuehn MR, Bradley A, Robertson EJ, Evans MJ (1987) A potential animal model for Lesch-Nyhan syndrome through introduction of HPRT mutations into mice. Nature 326:295-298.

Lalonde $\mathrm{R}$ (1987) Motor abnormalities in weaver mutant mice. Exp Brain Res 665:479-481.

Lloyd KG, Hornykiewicz O, Davidson L, Shannak K, Farley I, Goldstein M, Shibuya M, Kelley WN, Fox IH (1981) Biochemical evidence of dysfunction of brain neurotransmitters in the Lesch-Nyhan syndrome. N Engl J Med 305:1106-1111.

Mehler MF, Haas KZ, Kessler JA, Stanton PK (1992) Enhanced sensitivity of hippocampal pyramidal neurons from $m d x$ mice to hypoxia-induced loss of synaptic transmission. Proc Natl Acad Sci USA $89: 2461-2465$.
Menke A, Jockusch H (1991) Decreased osmotic stability of dystrophin-less muscle cells from the $m d x$ mouse. Nature 349:69-71.

Messer A, Plummer J, Maskin P, Coffin JM, Frankel WN (1992) Mapping of the motor neuron degeneration ( $m n d)$ gene, a mouse model of amyotrophic lateral sclerosis (ALS). Genomics 18:797-802.

Nagatsu T, Levill M, Udenfriend $S$ (1964) A rapid and simple radioassay for tyrosine hydroxylase activity. Anal Biochem 9:122-127.

Nave KA, Lai C, Bloom FE, Milner RJ (1986) Jimpy mutant mouse: a $/ 4$-base deletion in the mRNA for myelin proteolipid protein and evidence for a primary defect in RNA splicing. Proc Natl Acad Sci USA 83:9264-9268.

Nyhan WL (1973) The Lesch-Nyhan syndrome. Annu Rev Med 24: $41-60$.

Popko B, Puckett C, Lai E, Shine HD, Readhead C, Takahashi N, Hunt SW, Sidman RL, Hood L (1987) Myelin deficient mice: expression of myelin basic protein and generation of mice with varying levels of myelin. Cell 48:713-721.

Raisman-Vozari R, Hirsch E, Javoy-Agid F, Vassort C, Savasta M, Feuerstein C, Thibault J, Agid Y (1991) Quantitative autoradiography of tyrosine hydroxylase immunoreactivity in the rat brain. $J$ Neurochem 57:1212-1222.

Readhead C, Popko B, Takahashi N, Shine HD, Saavedra RA, Sidman RL, Hood L (1987) Expression of a myelin basic protein gene in transgenic Shiverer mice: correction of the dysmyelinating phenotype. Cell 48:703-712.

Richter JA, Stotz EH, Ghetti B, Simon JR (1992) Comparison of alterations in tyrosine hydroxylase, dopamine levels, and dopamine uptake in the striatum of the weaver mutant mouse. Neurochem Res $17: 437-441$

Roberts E, Simonsen DG (1963) Some properties of L-glutamic decarboxylase in mouse brain. Biochem Pharmacol 12:113-134.

Roffler-Tarlov S, Graybiel AM (1984) Weaver mutation has differential effects on the dopamine-containing innervation of the limbic and non-limbic striatum. Nature 307:62-66.

Roffler-Tarlov S, Graybiel AM (1987) The postnatal development of the dopamine-containing innervation of dorsal and ventral striatum: effects of the weaver gene. J Neurosci 7:2364-2372.

Roffler-Tarlov S, Pugatch D, Graybiel AM (1990) Patterns of cell and fiber vulnerability in the mesostriatal system of the mutant mouse weaver. II. High affinity uptake sites for dopamine. J Neurosci 10: 734-740.

Rossant J (1990) Manipulating the mouse genome: implications for neurobiology. Neuron 2:323-334.

Schmidt MJ, Sawyer BD, Perry KW, Fuller RW, Foreman MM, Ghetti B (1982) Dopamine deficiency in the weaver mutant mouse. J Neurosci $2: 376-380$.

Sicinski P, Geng Y, Ryder-Cook AS, Barnard EA, Darlison MG, Barnard PJ (1990) The molecular basis of muscular dystrophy in the $m d x$ mouse: a point mutation. Science 244:1578-1580.

Silverstein FS, Johnston MV, Hutchinson RJ, Edwards NL (1985) Lesch-Nyhan syndrome: CSF neurotransmitter abnormalities. Neurology 35:907-911.

Simon JR, Ghetti B (1992) Topographic distribution of dopamine uptake, choline uptake, choline acetyltransferase, and GABA uptake in the striata of weaver mutant mice. Neurochem Res 17:431-436.

Triarhou LC, Ghetti B (1987) Neuroanatomical substrate of behavioural impairment in weaver mutant mice. Exp Brain Res 68:434436.

Triarhou LC, Norton J, Ghetti B (1988) Mesencephalic dopamine cell deficit involves areas $\mathrm{A} 8, \mathrm{~A} 9$ and $\mathrm{A} 10$ in weaver mutant mice. Exp Brain Res 70:256-265.

Tybulewicz VLJ, Tremblay ML, LaMarca ML, Willemsen R, Stubblefield BK, Winfield S, Zablocka B, Sidransky E, Martin BM, Huang SP, Mintzer KA, Westphal H, Mulligan RC, Ginns EI (1992) Animal model of Gaucher's disease from targeted disruption of the mouse glucocerebrosidase gene. Nature 357:407-410.

Voorn P, Kalsbeek A, Jorritsma-Byham B, Groenewegen HJ (1988) The pre-and postnatal development of the dopaminergic cell groups in the ventral mesencephalon and the dopaminergic innervation of the striatum of the rat. Neuroscience 25:857-887.

Watts RWE, Spellacy E, Gibbs DA, Allsop J, McKeran RO, Slavin GE (1982) Clinical, postmortem, biochemical and therapeutic observations on the Lesch-Nyhan syndrome with particular reference to the neurological manifestions. Q J Med 201:43-78.

Waymire JC, Bjur R, Weiner N (1971) Assay of tyrosine hydroxylase 
by coupled decarboxylation of dopa formed from $1-{ }^{14} \mathrm{C}-\mathrm{L}$-tyrosine. Anal Biochem 43:588-600.

Westerink BHC (1985) Sequence and significance of dopamine metabolism in the rat brain. Neurochem Int 7:221-227.

Williamson DJ, Sharkey J, Clarke AR, Jamieson A, Arbuthnott GW, Kelly PAT, Melton DW, Hooper ML (1991) Analysis of forebrain dopaminergic pathways in HPRT ${ }^{-}$mice. Adv Exp Med Biol 309B: $269-272$.
Wood PL, Altar CA (1988) Dopamine release in vivo from nigrostriatal, mesolimbic, and mesocortical neurons: utility of 3-methoxytyramine measurements. Pharmacol Rev 40:163-187. Yarbrough GG, McGuffin-Clineschmidt J, Singh DK, Haubrick DR, Bendesky RJ, Martin GE (1984) Electrophysiological, biochemical, and behavioral assessment of dopamine autoreceptor activation by a series of dopamine agonists. Eur J Pharmacol 99:73-78. 